NUCLEAR INSTRUMENTS AND METHODS 50 (1967) I79-180; C NORTH-HOLLAND PUBLISHING CO.

\title{
A STRETCHED FOIL SAMPLE HOLDER FOR LIQUIDS
}

\author{
T.E. SAMPSON* and J.M. CARPENTER
}

Department of Nuclear Engineering, The University of Michigan, Ann Arbor, Michigan, U.S A.

Recelved 19 December 1966

A very thin walled liquid sample holder using $0.002^{\prime \prime}$ stretched aluminum foll windows has been described by Striffler and Carpenter ${ }^{1}$ ). This target has been acknowledged to have the thinnest windows so far reported for targets of this type ${ }^{2}$ ).

A modified version of this sample holder (figs. 1 and 2) has been developed which uses the stretched foll principle and is similarly intended for use under atmospheric conditions. It has several advantages over the target of Striffler and Carpenter. It is easier to fabricate since it has no critical dimensions. Assembly and fillıng are rapid since the windows stretch taut quickly and easily. Greater freedom of choice of materials which contact the enclosed sample is permitted by the new stretching method. Thin halocarbon films such as Teflon FEP, Aclar, and possibly others, as well as aluminum, can be used because of the increased stretching ability of this design. Halocarbon films are nearly impervious to accidental damage and can be used to contain corrosive liquids that are incompatible with aluminum.

The foils are clamped between the upper and lower body pieces and a Teflon O-rıng making a lıquid tight seal. Other rigid seal ring materials might be used. The O-ring thickness determines the amount of stretching of the forls and in turn is determined by the

* Atomic Energy Commission pre-doctoral Fellow in Nuclear Science and Engıneerıng.

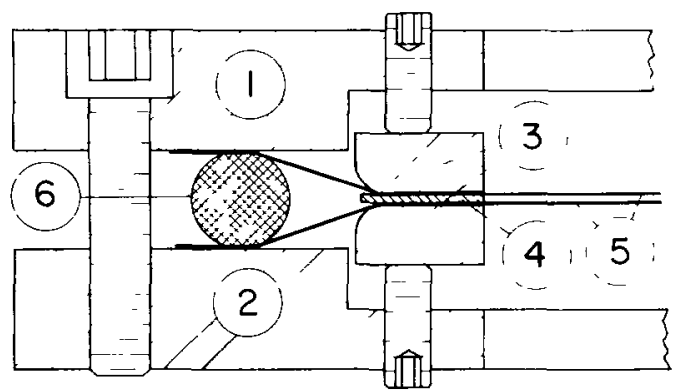

Fig. 1. Cross section of assembled sample holder. 1. upper body; 2. lower body, 3. clamp rıngs, 4. spacer ring; 5 foll windows, 6 . Teflon $\mathrm{O}$-ring.
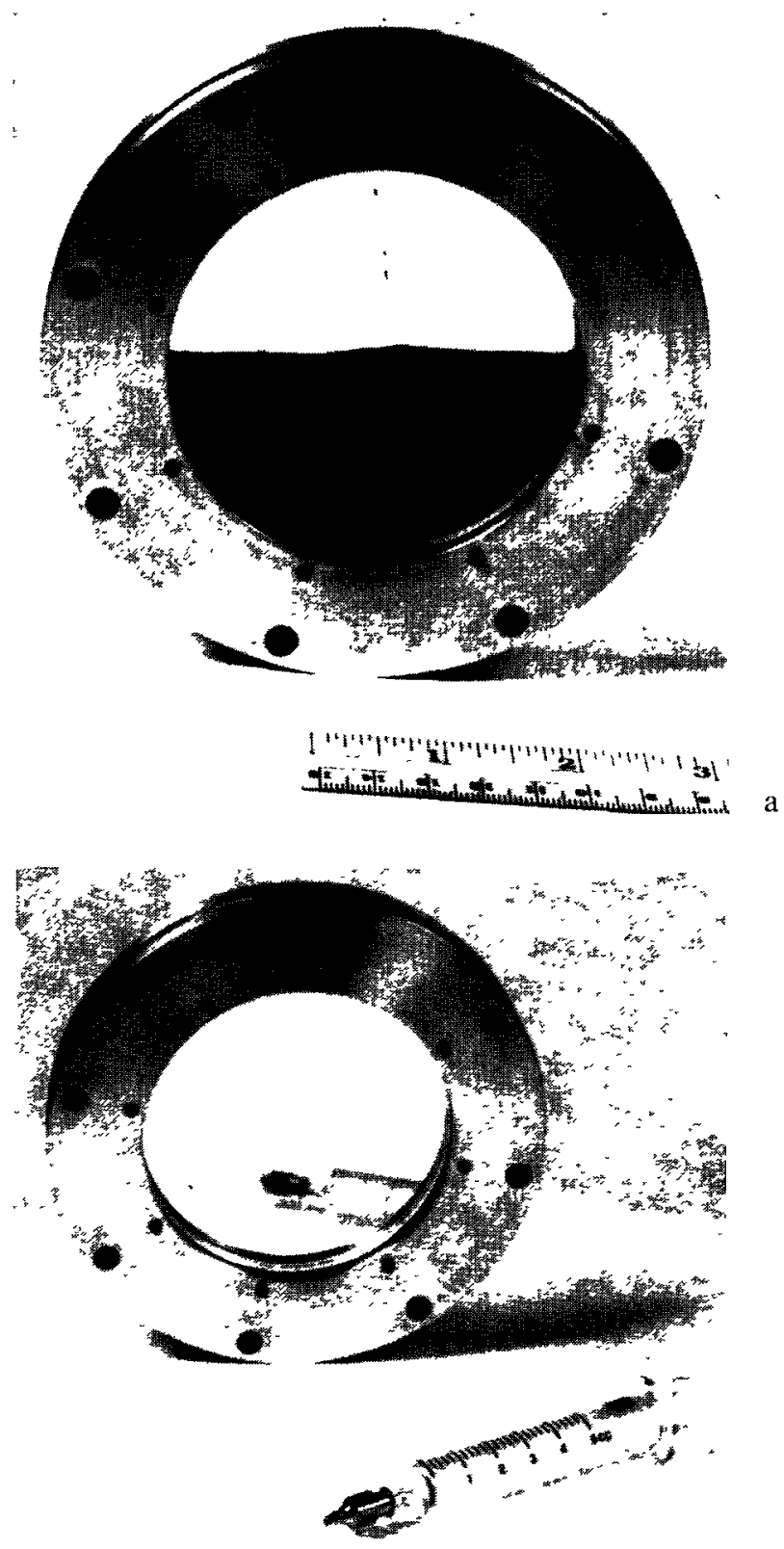

b

Fig. 2 The assembled sample holder a. with $0.005^{\prime \prime}$ Aclar windows, partially filled with colored water. The scale is graduated in inch (upper) and $\mathrm{cm}$ (lower); b with $0.0015^{\prime \prime}$ alumınum windows. 
target diameter and the type and thickness of windows used.

Tests were made with a Teflon O-ring of $4.00^{\prime \prime}$ ı.d. and $0.200^{\prime \prime}$ dia. cross section, a $3.19^{\prime \prime}$ dia. target (5.125" overall dia.) and a $0.015^{\prime \prime}$ spacer, using 0.002 " aluminum and $0.005^{\prime \prime}$ Aclar $33 \mathrm{C}$ forls. The bulging of the aluminum foils was 0.002 " $-0005^{\prime \prime}$ while the Aclar bulged $0.007^{\prime \prime}$. Bulging, defined as the difference in thickness between the filled and empty targets at the target center, is easily measured with a depth micrometer. With the same target it was necessary to use a $0.375^{\prime \prime}$ cross sectıonal dia. O-rıng to stretch $0.002^{\prime \prime}$ Aclar with a bulging of $0.007^{\prime \prime}$.

The empty target is assembled while lyıng flat by tıghtenıng the upper and lower target body pieces against the foils and the O-ring while the clamp ring screws are retracted. The foils are then stretched taut by the clamp rings when the eight equally spaced screws are gradually tightened top and bottom alternately around the periphery. Too much tightening of the clamp rings will wrinkle an aluminum forl window. The target is filled with a hypodermic syringe through fill and vent holes drilled in the O-rıng opposite a gap in the spacer. The target is filled until it overflows from the fill and vent holes. This ensures that the region between the spacer and O-rıng is filled since the clamp ring-foll-spacer is not liquid tight.
It has been found helpful with certain types of aluminum foll windows to place a thin ring of Teflon between the clamp rings and the foils to reduce the possibility of the folls tearıng durıng the stretching process.

Aluminum foll targets can be X-rayed for volds as outlined $\mathrm{in}^{1}$ ). The nearly transparent halocarbon film targets can be examıned visually both durıng filling and in use, a highly desirable feature

Halocarbon film targets produce a somewhat higher background than aluminum in neutron scattering experıments. In all cases the halocarbon films bulged significantly more than alumınum foils and among the halocarbons tested, the bulging was greater for Teflon FEP than for Aclar. Aluminum foll targets have the advantage of reduced target bulk since the thinnest folls can be stretched taut with thinner O-rings.

The authors wish to thank the Aluminum Company of America, E.I. duPont de Nemours \& Company. and Allıed Chemical Corporation for providing the foils for this work.

\section{References}

1) C D. Striffler and J M. Carpenter, Nucl Instr. and Meth 24 (1963) 395.

2) J A R. Griffith and E J Burge, Rev Scı Instr 37 (1966) 147. 